\title{
Uprising on West Bank places strains on academics
}

Jerusalem

THE intifada, or uprising, in the Israelioccupied West Bank and Gaza Strip has forced both Palestinian and Israeli academics to make difficult choices. Palestinians have expressed solidarity with the new leadership. For their Jewish Israeli counterparts, the six-month-old uprising has exacerbated the split between left and right

Calls for commercial strikes, stonethrowing mêlées and defiance of Israeli tear gas and rubber bullets have brought life in the territories to a virtual standstill. The West Bank universities have been shut by the Israelis since February.

The students have caused "a breakdown of the social structure" according to Dr Baeb Erakat, lecturer in political science at A-Najah University in Nablus.

But, "the social transformation has brought [us all] closer together", he said, noting that it is the "generation of occupation, of defiance, which is leading the uprising". In fact, 77 per cent of the Palestinian population in the occupied territories is under 28 years old.

"The general tendency [among Palestinian academics] now is to go back to the people, to seek out their roots", says Dr Azmy Bishara of the philosophy department of the West Bank's Bir Zeit University.

So far, only one general proposal has been announced by a group of Palestinians that includes two academics. The 14point plan, unveiled three months ago, calls for an end to the occupation and condemns the mass arrests, deportations and other "illegal steps" taken by the Israeli army, which "contravene the Geneva Convention".

Gabi Baranki, professor of chemistry, acting president of Bir Zeit and one of the plan's signatories, says, "I don't believe peace is something to keep on talking about. Concrete steps must be taken."

But the Jewish academic community is further from a common political view than ever. A few weeks after the disturbances began, 600 academics banded together as the 'Inter-University Movement for a Political Settlement', and signed a petition calling on the Israeli government to negotiate with the Palestinians.

The group is still debating the extent to which it is prepared to recognize the Palestine Liberation Organization (PLO). It did, however, recently issue a statement requesting that Israel end its policy of not talking to the PLO.

Contact with the PLO, however, is anathema to a right-wing group that emerged in reaction to the first petition. 'Professors for a Strong Stand' came out in support of the army's tactics, which have left many Palestinians dead. Their petition boasted 700 signatures although they have been accused of turning to hospital physicians and other 'non-academics' to boost their numbers.

"We got irritated by those who came out in the name of the academic community, condemning the army for its actions in the territories", said Professor Hefzibah Eyal-Giladi, of the Hebrew University's biology department, who believes that Israel's reaction to the intifada "was too little, too weak"

One point made by Eyal Giladi and shared by many other Jewish Israelis is that there is no one to negotiate with. "The PLO is a tricky business; what it says one day is not the same as another day", says Leo Sachs, head of the Weizmann Institute's biology department. But Sachs also says that there must be a modus vivendi between the two communities, and that although the search for a settlement is bound to take time, it would be a "good idea" if the academic community

\section{Apology}

IN a News article entitled "Japanese AIDS scandal over trials and marketing of coagulants" (Nature 331, 552; 1988), we stated that Professor Takeshi Abe of Teikyo University had admitted delaying approval of clinical trials and marketing of heat-treated blood coagulants for haemophiliacs so that a Japanese blood-product manufacturer could catch up with foreign competition.

We now understand this statement to be incorrect. Professor Abe helped to coordinate clinical trials of heat-treated coagulants and has explained that the advice he gave to the companies involved was intended to speed licensing. He further explained that the need for coordination, intended to ensure that licences would be granted without delay by the ministry's new drugs committee, may have given rise to the impression that some activities were being held back.

We also reported the Mainichi newspaper as saying that Professor Abe solicited donations from the companies involved in the clinical trials during the time they were trying to win approval for trials. We fully understand that all donations given to Professor Abe had no connection with the execution of the trials and were used to help realize Professor Abe's dream of establishing a foundation to aid haemophiliacs.

Nature regrets these errors and apologizes to Professor Abe for them. were to develop a workable plan.

The Palestinian academics, for their part, claim the right of their people to choose their own leaders, and reject Israeli moves to do this for them. As Erakat points out, a 1986 poll shows that 93 per cent of the Palestinian people support the PLO as their sole legitimate representative, so the imbroglio is not likely to end soon.

Lisa Perlman

\section{Vote-catching oil debate in California \\ Berkeley}

OPPONENTS of the plans of the US Department of the Interior for oil exploration off the northern California coast have gained a temporary victory, thanks in part to the forthcoming presidential election. The department has agreed to postpone the plan, but most agree that the delay is politically motivated, and may end after the election.

The offshore leasing plan has come under harsh criticism not only by Californians, but also by the Environmental Protection Agency and the US Fish and Wildlife Service, and most recently by presidential candidates courting the Californian vote.

Democratic candidate Michael Dukakis has promised to cancel the sale of leases for oil exploration on 1.1 million acres off the Mendocino coast. Republican candidate George Bush, an ex-Texas oilman who supports offshore drilling, recently said he would reserve his stand on the California plan until more is known about potential environmental impacts. Opponents of the drilling plan see Bush's change of heart as a political move in response to reports that California voters favour Dukakis. Most expect that Bush would proceed with the oil exploration if elected.

The day after Bush's announcement, and apparently in response to Republican pressure, Interior Secretary Donald Hodel called for an indefinite suspension of the lease sale, originally scheduled for February 1989 . Hodel cancelled publication of a final environmental impact report that was due out in August.

There has been much criticism of the preliminary environmental impact report, published last December. An Environmental Protection Agency request for further habitat protection (see Nature 332, $673 ; 1988$ ) was followed by even harsher criticism by the US Fish and Wildlife Service, an agency of the Interior Department.

Last week, the interior subcommittee of the House Appropriations Committee voted, without discussion, to delay any drilling in the area until October 1989. The full committee is expected to support the decision, given the current political volatility of the issue. Marcia Barinaga 